Transportation Research Forum

Book Review: Privatizing Toll Roads: A Public-Private Partnership

Book Author(s): Wendell C. Lawther

Review Author(s): Gabriel Roth

Source: Journal of the Transportation Research Forum, Vol. 44, No. 3 (Fall 2005), pp. 165-166

Published by: Transportation Research Forum

Stable URL: http://www.trforum.org/journal

The Transportation Research Forum, founded in 1958, is an independent, nonprofit organization of transportation professionals who conduct, use, and benefit from research. Its purpose is to provide an impartial meeting ground for carriers, shippers, government officials, consultants, university researchers, suppliers, and others seeking exchange of information and ideas related to both passenger and freight transportation. More information on the Transportation Research Forum can be found on the Web at www.trforum.org. 


\section{Privatizing Toll Roads - A Public-Private Partnership}

\section{by Gabriel Roth}

In 2004 a private consortium agreed to pay the City of Chicago $\$ 1.83$ billion for a lease allowing it to collect tolls on the city-owned "Skyway" for 99 years. Other states, including California, Delaware, Indiana, New Jersey, New York, Texas and Virginia, are considering similar deals. Should officials in those states study Wendell Lawther's new book?

Privatizing Toll Roads - A Public-Private Partnership describes in great detail the contracting out in 1995 of toll operations by the Orlando-Orange County Expressway Authority (OOCEA) to Florida Toll Services (FTS), a Morrison-Knudsen/Parson-Brinckerhoff joint venture. It describes the following stages in the process:

- $\quad$ Reaching the decision to privatize;

- Preparing the "Request for Proposals;"

- Evaluating the bids;

- Awarding the contract to the winning bidder;

- $\quad$ The transition to the privatized operation; and

- Monitoring the private contractor.

The descriptions are comprehensive and generally based on discussions with the people concerned and perusal of original documentation. The privatization process coincided with the introduction of automatic vehicle identification (AVI) and electronic toll and traffic management (ETTM).

The decision to privatize the toll collection operations of the OOCEA, which had previously been the responsibility of the Florida Department of Transportation, was taken to achieve four objectives:

- To reduce costs;

- To improve the quality of service to the public;
- To improve accounting and auditing; and

- To improve the management flexibility of the OOCEA.

All the objectives appear to have been successfully achieved. Additionally, labor relations remained good, with the new contractor employing all existing staff willing to work for it.

The problem with this valuable book is its title: Contracting-out toll collection services could be part of a privatization operation, but "privatizing toll roads" involves other issues also. For example, highway maintenance might have been contracted out. More fundamental issues not discussed in the book are:

Who is to own the toll road? The first modern US Toll Expressway, the Long Island Motor Parkway, was privately built between 1907 and 1911, and privately owned, as is the Dulles Greenway near Washington, D.C. Other toll roads, such as the Chicago Skyway mentioned above, are owned by a government agency and leased to a private entity.

How are toll levels to be determined? The toll level on the OOCEA roads was not discussed in the book. Of particular interest is the possibility of variable tolls, with higher fees during the day to ensure congestion-free travel at all times. The California Private Transportation Company was required to impose such variable charges on the Express Toll lanes it established in 1995 on California's State Route 91.

Competition from government-owned "free" roads: Can, or should, private toll road operators be protected from such competition by means of "non-compete" clauses in their contracts?

It can be concluded that Wendell Lawther's book is essential reading for all road operators 
interested in contracting out their toll collection services. But a comprehensive discussion of "Privatizing Toll Roads" it is not. It would be instructive if Mr. Lawther were to deal with the broader issues in his next book.

Gabriel Roth, a Research Fellow of the Independent Institute, is the author of Roads in a Market Economy (1996), and editor of the forthcoming Independent Institute publication Street Smart Competition, Entrepreneurship and the Future of Roads (Transaction Publishers, 2006). 